\title{
Developing Critical Thinking in English Class: Culture-based Knowledge and Skills
}

\author{
Mei Guo \\ School of Foreign Languages, Dalian University of Technology, Dalian, China
}

\begin{abstract}
Critical thinking is central to education, but the majority of English language classes in China fail to teach critical thinking skills. In order to help students to develop critical thinking skills, this paper examines the underlying values that produce the variety of culturally derived thinking dispositions so as to demonstrate the influence of Chinese thinking disposition on student' critical thinking development. Suggestions are made for culture -based instructions as an educational conception of critical thinking in language teaching.
\end{abstract}

Index Terms - critical thinking, culture-based instruction, language teaching

\section{INTRODUCTION}

Critical thinking is the ability and willingness to assess claims and make objective judgments on the basis of well-supported reasons and evidence rather than emotion or anecdote. (Wade and Tavris, 2008) It is not only about cognitive capabilities but also about moral commitment to the critical standards and traits. The critical part of critical thinking should be understood as a reference to the values desired by a certain community and expected to guide the thinking of its members.

It is no controversy that critical thinking is central to education, and it should be taught in every language courses. However, as an English teacher, I find that the majority of college English classes in China fail to teach critical thinking skills and, as a result, most of our students do not practice it in language learning. In order to help Chinese students to develop critical thinking skills, this paper will examine the underlying value structures that produce the variety of culturally derived thinking dispositions so as to demonstrate the influence of Chinese thinking disposition on student' critical thinking development. Suggestions are made for culture -based instructions as an educational conception of critical thinking.

\section{Dimensions of CUltural Variation AfFecting Thinking Dispositions}

Most theories of critical thinking emphasize the importance of thinking dispositions, or cognitive styles, that refer to one's attitude toward belief, and especially one's attitudes toward forming and changing beliefs (Stanovich, 2009). Thinking dispositions do not directly affect people's ability to implement critical thinking; rather, they influence the direction and strength of that thinking (Nickerson, 2008).

While not all thinking disposition is a logical outgrowth of the culture where it developed, most of it is. As most thinking disposition is culturally based, what it reflects often is a case of what a culture has transmitted to its members. Actually people from different cultures abstract whatever fits into their personal world of recognition and then interpret it through the frame of reference of their own culture. Their beliefs, statements and actions are depending on their cultural background assumptions.

\section{A. Agrarian and Commercial Culture}

The culture system is grounded, as highly particular meanings are being projected from a very particular past. Similar symbols and forms may occur in various societies, but the sense which they speak, the system of which they are a part, is of a particular place and time. Definitions of culture run the gamut from "an all-encompassing phenomenon" to descriptions listing nearly all human activity. For my purpose, I choose the definition: Culture is "a historically transmitted pattern of meanings embodied in symbols, a system of inherited conceptions expressed in symbolic forms by means of which men communicate, perpetuate and develop their knowledge about and attitudes towards life" (Geertz, 1973). In this sense, culture is not the history of a symbol, or form, but grounded in historical systems of symbols, symbolic forms, and their meanings (Samovar and Porter, 1994).

To talk about the origin and development of some of the distinguishing features of western culture, we must remember the premise that in all essentials the culture is derived from that of Greek, one of the earliest coastal states that develop commerce. Based on the navigational foundation, Western culture became a commercial culture characterized as adventurous and challenging.

As for Chinese culture, it is clear that no single factor can explain the "special character" of Chinese civilization. But Chinese and Western scholars have long recognized the close relationship between the land and the people in China. Nowhere else have so many people lived so intimately with nature. To Chinese farmers the soil is the root of their lives. 
They cannot move their land or the crops they grow. They seem to have planted half their own bodies into the soil, waiting for their crops to mature. In addition, throughout its long history, China has been surrounded by formidable geographic barriers, which have impeded direct contact with other advanced civilizations. This geographic isolation unquestionably contributed to the unity and continuity of Chinese civilization and fostered a profound sense of cultural distinctiveness and superiority. Therefore based on the rural foundation and geographic isolation, Chinese culture became an agrarian culture characterized as stable and reserved.

\section{B. Collectivism and Individualism}

The degree to which a culture is individualistic or collectivistic has an important impact on the thinking dispositions. Emphasis is placed on individuals' goals in individualistic cultures, while group goals have precedence over individuals' goals in collectivistic cultures.

Individualism lies at the very core of Western culture. Indeed, the best and the worst features of western culture can be attributed to individualism. Proponents of individualism have argued that it is the basis of liberty, democracy, freedom and economic incentive. The emphasis on private achievement and maximum individual freedom embodied in this view of individualism was obviously in harmony with capitalist notions of individualism initiative, economic competition and personal profit.

In China, however, the corresponding value that forms the nexus of society is collectivism. Chinese generally think of themselves as being members first of all, of a group. The group is most important, and Chinese people are likely to have relatively few important contacts outside the group. This means that group interactions are particularly intense and group members know each other exceptionally well. What's more, much influenced by the Confucian thought, China is a family-centered society where family is put ahead of all other groups. The primary duty of a Chinese is to his extended family that in turn provides the needy individual member with social, moral, spiritual, and material support. On no account would a Chinese refuse to shelter a member of his extended family in distress. Moreover, the friendships of a Chinese are to some extent predetermined by stable relationships formed early in life. Therefore, Chinese follow two types of friendship formation sequences: interpersonal relationships cultivated and maintained as a result of social obligation; and personal friends, or class relationships that develop from mutual liking, attraction, interests or common values.

\section{High and Low Context}

An essential dimension of intercultural communication is that of context. The importance of the role of context is widely recognized in the communication fields. "A high context (HC) communication or message is one in which most of the information is either in the physical context or internalized in the person, while very little is in the coded, explicit, transmitted part of the message. A low context (LC) communication is just the opposite; i.e. the mass of the information is vested in the explicit code." (Hall, 1976).

Low-context Westerners focused on discrete information. Each time they interact with others they need detailed background information. They need to know what is going to be in what compartment before they commit themselves. In this way, messages are usually elaborated, clearly communicated, and highly specific. They are often perceived as excessively talkative, belaboring the obvious, and using redundancies.

With extensive information networks among family, friends, colleagues, and clients, high-context Chinese are usually involved in close personal relationships. In contrast to the Western significance of eloquence and self-assertion, the general attitude of Chinese toward language and verbalization is that fewer words are better than more words. Researchers found that people who were more verbal were perceived as more attractive by people in the United States, but people who were less verbal were perceived as more attractive in China.

\section{Femininity and Masculinity}

Masculinity is a neglected dimension of culture. High masculinity, involves a high value placed on things, power, and assertiveness, while systems in which people, quality of life, and nurturance prevail are high on femininity. Cultural systems that are high on the masculinity index emphasize differentiated sex roles, performance, ambition, and independence. Conversely, systems low on masculinity value fluid sex roles, quality of life, service, and interdependence. Attributes like strength, assertiveness, competitiveness, and ambitiousness are considered to be typical masculine traits, whereas attributes like affection, compassion, nurturance, and emotionality are regarded as feminine traits.

According to Hofstede (1982), Western countries, regarding ambitiousness and assertiveness as important, tend to be a masculine country. Ambition is one of the typical traits of a masculine culture. In US the idea instilled into the minds of most boys, from an early age, is that of "getting on." Like the heroes of Horatio Alger novels, nineteenth-century Americans were continually entreated to strive for personal achievement. That is why modern social scientists have often claimed that an emphasis on achievement is an integral feature of American culture. Americans assert that everyone should try to amount to more than his parents did and affirm that they regard themselves as rather ambitious at heart. Assertiveness or dominance is another main dimension along which social behavior varies. In the USA social skills training has concentrated on assertiveness, presumably reflecting a widespread approval of and desire to acquire assertive behavior. 
On the other hand, placing more importance on patience and compassion, Chinese culture is to some extent more feminine. In a Chinese household with many generations living under the same roof, patience is essential in keeping a peaceful family. Every member has to do his or her share of compromising. Patience is the invisible force which purifies passions so as to bear the infirmities of one another, and to tolerate the diversified opinions and transgressions of one another. Patience is therefore the essence of etiquette, ethic, and more importantly, harmony. Moreover, feminine Chinese tend to be more compassionate and dependent. Observations of mother-child interactions in Chinese families and in American families indicate that American mothers seem to foster independence in their children, while Chinese mothers tend to foster dependence. Compassionate Chinese mothers, as a rule, would pick up their infants almost as soon as they began crying and hold them until the babies went to sleep. In contrast, American mothers would let their children cry until they fell asleep.

\section{Culture-BASed Instructions as AN Educational CONCEPTION OF CRITICAL Thinking}

In recent years, college teachers are coming to realize that efforts to develop critical thinking skills must be included in language learning. However, in China where students grow up engaged with passive learning, cultivating critical thinking is one of the most difficult tasks in class. Educators agree that understanding the differences in thinking dispositions between different cultures will help students to develop critical thinking.

Hall (1969) in his book The Hidden Dimension makes the point that you can not shed your culture, you cannot erase it, and that it can penetrate at the very roots of your nervous system. Culture determines not only the specific verbal and nonverbal behavior that represents or symbolizes specific thought, feeling, but also when it is appropriate to display or communicate various thoughts, feelings, or internal states. Educators agree that it is important to understand the role of culture and its characteristics and potential impact on thinking dispositions in a variety of ways. In fact, some Chinese cultural dimensions have become barriers to the development of good critical thinking skills.

\section{A. Cultural Dimensions Affecting Students' Development of Good Critical Thinking Skills}

As Chinese agrarian culture emphasizes respect for and obedience to the authority, language teachers usually dominate the class and do most of the talking, while most students are busy taking notes. In this way, students become passive receivers instead of active thinkers. And face-to-face conversations between teachers and students contain many emollient expressions of respect and courtesy, while directness and especially criticism are much disliked. Actually, in China, we do not appreciate external criticism. In social interactive situations, the concept of face is tied closely to one's self-respect. Even if it is a conversation between peers, students are reserved when criticizing others because they think it will make others losing face.

In Chinese collectivistic culture, harmony and cooperation among the group tend to be emphasized more than individual achievement and freedom. Chinese people regard compliance with norms as a primary value and unique individual beliefs as a secondary value. We emphasize goals, needs, and views of the group over individual outcomes. Therefore, it is not surprising that, students show more synchrony in their opinions. When students were asked to have group discussion, they may suppress both positive and negative opinions that are contrary to the idea of the group because maintaining the group is a primary value. At the same time, group members try to decode other members' thought to find out what their true positions are, since group members do not necessarily state their positions openly. Within groups, decisions are often made by reaching a consensus. This is a long, drawn-out process in which group members talk around the subject of the decision, sounding out one another's positions, until they can arrive at a decision that everyone in the group can agree with.

For high-context Chinese, the simple statement, "To talk little is natural," is obviously and experientially descriptive. Most Chinese agree with the saying, "Out of the mouth comes all evil." Chinese are more comfortable with silence and believe that they can communicate in silence. Actually, Chinese are apt to become impatient and irritated when people insist on giving them information they don't need. Too much information makes people feel they are being talked down to. As a result, students in English class consider it a virtue to say little and tend to use nonlinguistic means to convey the rest. They assume that the other fellow understand without their saying it.

While Westerners are perceived as assertive, feminine Chinese are not. Submissiveness and the maintenance of pleasant social relations are valued more. That is why, in English language learning, students are shy of expressing their ideas, because they are afraid of being hurt. They tend to be more active when having a group discussion, but there are few students volunteer to present their ideas individually.

\section{B. Culture-based Instructions for Developing Good Critical Thinking Skills}

Success in most professions requires good critical thinking skills. Our most everyday activities require us to make use of some of the basic skills involved in critical thinking, such as: taking steps to find out whether something is likely to be true; arguing our own case if someone doesn't believe us. However, just because we can think critically this doesn't mean we always do, or that we do it well. This is to be expected, as we don't need to employ the same level of critical thinking for everything we do. (Cottrell, 2005)

Critical thinking is broadly seen as the kind of logical thinking that helps us to analyze and make sense of, or interpret, all forms of situations or information so that the conclusions we draw from our interpretations are sound. The 
etymology of the English word shows that thinking and knowledge are derived from the same root. Therefore, if teachers wish to cultivate students' critical thinking in language class, they should both introduce culture-based knowledge and apply new teaching methods. The question which arises next is how to do it. Here are some suggested procedures:

One important step in helping students to develop critical thinking is having an understanding of the target culture itself. It emphasizes informational aspects of learning. Teachers could teach common parts of the target culture, so that students will recognize them and understand them when they encounter them. One way is to assign readings including different thinking dispositions. The priority might be to teach verbal codes that have negative meanings in the target culture. Understanding different thinking disposition in reading assignments will increase the students' understanding of the text. At its best it will be necessary to practice both reading and writing at the same time for enabling critical thinking.

Although verbal means has been the primary focus in language teaching for many years, scholars have come to agree that the study of communication is incomplete without the consideration of the meaning conveyed by nonverbal means. Nonverbal communication which makes use of space, time, vocal sounds, the eyes, touch, actions, objects, can serve to complement, regulate, and substitute verbal communication. To be an effective communicator, one needs to become receptive to nonverbal cues in understanding others' total series of messages. Therefore, it is not enough that English teachers teach the language only. It is also necessary for them to teach the nonverbal codes in the target language.

While providing information about different cultures, teachers should be trained how to ask questions appropriately and effectively. (Shen, 2012) At the heart of teaching critical and creative thought is the ability to ask the right questions to students. The method of teaching critical thinking skills requires students to engage in independent thinking such as problem solving, analyzing and evaluating information. While the students answer the questions, teachers give explicit instruction in it by praising or criticizing certain ways of thinking and responding.

But the most significant aspect of developing critical thinking may be conveyed implicitly, not by lesson but through brainstorming. Group discussion may be the most widely used behavior in language teaching. Discussion about the cultural differences is one of the most effective ways to reinforce the individual for producing behavioral patterns which are likely to develop critical thinking. Other methods which can more easily be employed by language class involve role plays. The role plays that a teacher already uses might be expanded to include various areas of developing critical thinking. For example, teachers can give students various concepts on slips of paper (e.g. "greetings between two strangers"), and have students act them out. Some students could demonstrate the first greeting between two strangers for different situations, while other students argue about the appropriate ways. The aim should not be to teach behaviors, but rather to develop critical thinking about another culture.

Assessment can also provide an additional, important incentive for critical thinking. The assessment's emphasis on open ended possibility reinforces the opportunities inherent in critical thinking. Using this form of assessment encourages students to execute what is being asked of them actively. (Mendelman, 2007) That helps teachers adjust their design and strengthen their determination to assist students in critical thinking development.

In a word, the language class should be organized to help students build their skills in critical thinking. Starting from a basic understanding of cultural differences to brainstorming the different behavior in different culture helps students to recognize the cultural differences associated with critical thinking and barriers to the development of good critical thinking skills. From applying techniques and strategies when reading and listening to producing their own critical writing and speech, the students will build their own skills in critical thinking. As various disciplines have contributed theories relevant to critical thinking development, there should be a conceptual framework to assemble all the fragments of critical thinking from various disciplines into a coherent, comprehensive, and powerful entity. (Phung, 2010)

\section{CONCLUSION}

Culture is an abstract term that defines a broad range of activities in which individuals express themselves. Culture is important because it tells us in different degrees what we are expected to think, say, and behave in typical life situations Due to the different origin and development in culture systems, Chinese and Western cultures display different cultural traits that attribute to the differences in their thinking dispositions. For example, while commercial westerners tend to be adventurous and challenging, agrarian Chinese are more reserved and stable; the "I" identity has precedence in individualistic western cultures, but the "we" identity takes precedence in collectivistic Chinese culture; Westerners from low context cultures are often perceived as excessively talkative, while Chinese from high context cultures may be perceived as mysterious; feminine Chinese regard patience and compassion as important, yet masculine westerners place more importance on ambitiousness and assertiveness.

In fact, these cultural dimensions have a great impact on the thinking dispositions in a variety of ways that may become barriers to the development of good critical thinking skills. A practical understanding of the dimensions along which Chinese and Western cultures differ, combined with the knowledge of how cultural dimensions affect thinking dispositions can not only help to reduce ethnocentrism and make Westerners' thinking pattern less confusing and more interpretable, but also serve as a source of developing critical thinking skills.

As an English teacher, I suggest that one important place for Chinese to learn about critical thinking skills is in the language classroom. Programs may include testing students on verbal and nonverbal codes that westerners use in order 
to find out how much they already know, making students aware of the importance of cultural differences, and assigning students to make observations. Only by understanding the target culture will students conduct an unprejudiced examination of evidence that might question their beliefs and provide an impartial hearing of a viewpoint contrary to their own. Only by accepting the differences in different cultures, will students seek out and consider new evidence, new ideas, and new possibilities. Only by experiencing the target culture, will students be willing to ponder what might, could, or would happen differently if the facts of a claim were considered under different conditions or from a different perspective. Culture-based instructions will explicitly and systematically prepare students with knowledge, skills and attitudes necessary for their development as critical thinkers. It is hoped that cultivating critical thinking in English class will add flexibility and richness to the students' experience, and make them aware that there are many ways of behaving and perceiving the world. But one thing we must remember is that people change their behavior gradually through the insights that they accept, through convictions and views they adopt. Like Chinese, westerners are also in a constant change. It is up to language teachers continually to be prepared for this, to accept it, to correct their impressions and to set up new programs for students to develop good critical thinking skills.

\section{REFERENCES}

[1] Cottrell, Stella. (2005). Critical Thinking Skills: Developing Effective Analysis and Argument. New York: Palcrave Macmillan.

[2] Finn, Patrick. (2011). Critical thinking: knowledge and skills for evidence-based practice. Language, speech, and hearing services in schools Vol.42, 69-72.

[3] Geertz, C. (1973). The interpretation of cultures. New York: Basic Books.

[4] Hall, E.T. (1976). Beyond culture. Garden City, N.Y.: Anchor Books.

[5] Henrik Bohlin. (2009). Perspective-dependence and Critical Thinking. Argumentation 23:189-203.

[6] Hofstede, G. (1982). Culture's Consequences. Newbury Park, Calif.: Sage Publications.

[7] Mendelman, Lisa. (2007). Critical thinking and reading. Journal of adolescent \&adult literacy 51:5. 300-302.

[8] Nickerson,R. S. (2008). Aspects of rationality: Reflections on what it means to be rational and whether we are. New York, NY: Psychology Press.

[9] Phung, Thanh Ha. (2010). A Pilot Comprehensive Critical Thinking Education Framework in TESOL. In Azadeh Shafaei(eds.), Frontiers of Language and Teaching: Proceedings of the 2010 International Online Language Conference (IOLC 2010). Florida: Universal Publishers.

[10] Ramsey, Eric Ramsey. (2011). Somehow, Learning to Live: On Being Critical. Communication and Critical/Cultural Studies Vol. 8, No. 1, 88-92.

[11] Samovar, Larry A. \& Richard E. Porter. (1994). Intercultural communication. California: Wadsworth Publishing Company.

[12] Shen, ping. (2012). A Case Study of teacher's Questioning and Students' Critical thinking in College EFL Reading Classroom. International Journal of English Linguistics Vol.2 No. 1.

[13] Stanovich, K. E. (2009). What intelligence tests miss: The psychology of rational thought. New Haven, CT: Yale University Press.

[14] Wade, C. \& Tavris, C. (2008). Psychology (9th ed.). Upper Saddle River, NJ: Prentice-Hall.

Mei Guo was born in Wuhan, China in 1973. She received her master's degree in English Languages and Literature from Wuhan University, China in 1998.

She is currently a lecturer in the School of Foreign Languages, Dalian University of Technology, Dalian, China. Her research interests include cross-cultural communication and western culture. 